\title{
RECORDANDO A UN AMIGO
}

\author{
Cristina DE PERETTI \\ Facultad de Filosofía \\ UNED
}

Como muy acertadamente afirma Derrida, el duelo que sigue a la muerte se prepara y anticipa siempre mucho antes de dicha muerte: ese es el tiempo mismo de la vida, pero también el tiempo de la amistad. Y su ley. Esa ley que dicta que, entre los amigos, uno ha de morir necesariamente antes que el otro y que este último, por consiguiente, se queda solo ante ese acontecimiento terrible, singular y siempre único que es la muerte de su amigo, abocado ya exclusivamente al trabajo de duelo, a recordar al amigo, a llevarlo consigo el resto de su vida: "Die Welt ist fort, ich muss dich tragen", aseguraba Paul Celan. "El mundo se ha ido, tengo que llevarte".

Todos los que lo conocimos sabemos de sobra el magnífico profesor, pensador e investigador que fue Quintín Racionero, todos hemos tenido el privilegio de escuchar esas clases, charlas y conferencias suyas presididas por esa oratoria única que lo caracterizaba, todos hemos tenido asimismo ocasión, una y otra vez, de comprobar sus apabullantes conocimientos en tantos y tantos campos del saber. Dicho de otro modo, todos somos conscientes de lo mucho que Quintín nos ha podido enseñar y legar en todos estos ańos que ha dedicado al estudio, al pensamiento y a la docencia.

No es, sin embargo, tanto a ese Quintín filósofo y docente al que yo quiero recordar aquí cuanto a ese otro Quintín, a la vez otro y el mismo, que fue mi amigo. Aunque, antes que nada, sí me gustaría dejar constancia del agradecimiento que los miembros del Departamento de Filosofía de la UNED le debemos por el impulso que, mientras fue su Director, le dio a nuestro Departamento creando, por ejemplo, su primera página web, fomentando sus 
seminarios de investigación permanente o consiguiendo la colaboración de la editorial Dykinson para futuras publicaciones, publicaciones de las que tantas personas de dentro y de fuera de dicho Departamento, profesores y estudiantes, nos hemos beneficiado desde entonces, e incluso tras su muerte, hasta hoy.

Ahora bien, insisto, es ante todo desde esa amistad que me honro haber mantenido con Quintín desde la que me gustaría acercarme aquí a él con la memoria y con el testimonio. Para eso, sin embargo, me faltan las palabras. Me faltan las palabras a pesar de ser tantas y tantas las cosas que podría decir de él. Ahora bien, ¿cuáles son las palabras oportunas para hablar de un amigo que ya no está entre nosotros? ¿Cómo hablar de él en lugar -como sería mi deseode hablarle a él, de hablar con él y de poder escuchar su voz? ¿Cuáles son las palabras apropiadas para expresar aquí mis sentimientos hacia Quintín, para explicar lo que él ha sido y ha significado para mí más allá de esa imagen suya de filósofo y de profesor? ¿Cómo declarar mi cariño y mi admiración hacia él en el tono más acertado? ¿Cómo dar testimonio de mi relación personal con él sin caer irremediablemente en cierto narcisismo encubierto o en una reapropiación del amigo que ya no está pero cuya alteridad nunca puede dejar de permanecer infinita para siempre? No lo sé.

Las primeras imágenes que tengo de Quintín se remontan a finales de los años 1970, en los pasillos de la Biblioteca de la Facultad de Filosofía de la Universidad Complutense. Yo sabía perfectamente quién era él pero no recuerdo que, por aquel entonces, intercambiásemos muchas más palabras que unos cordiales "buenos días" o "buenas tardes". Muchos años más tarde, Quintín se incorporó a la UNED como catedrático de Historia de la Filosofía Antigua. Fue entonces cuando, muy pronto, tuve la inmensa suerte de trabar amistad con él. Una amistad que fue creciendo con el tiempo pero que, desde el principio, decidimos de común acuerdo que debía de basarse en la sinceridad más absoluta entre nosotros. Lo cual en ocasiones nos acarreó algún que otro rifirrafe rápidamente superado, pero sobre todo nos permitió mantener una amistad verdadera hasta su muerte tan prematura. Y también más allá.

A esa suerte incomparable que he tenido de conocer a Quintín, de haber podido compartir con él todos estos ańos de compañerismo y de amistad desde su llegada a la UNED, no puede dejar de ir íntimamente unida la tremenda gratitud que siento igualmente hacia él por haber depositado en mí su confianza tanto a nivel personal, al considerarme su amiga, como a nivel intelectual, al contar conmigo para algunos de sus seminarios y proyectos de investigación. 
En este sentido también, mi deuda para con Quintín es incalculable y lo único a lo que aspiro, más allá de su muerte, es a estar hasta el final a la altura de esa confianza que él consideró que quería y podía otorgarme.

Cariño y amistad. Deuda y gratitud. Y, por supuesto, inmensa admiración hacia Quintín: esos son los sentimientos que Quintín despertó y siempre seguirá despertando en mí. Admiración, como es obvio, por esos raudales de inteligencia, de conocimientos y de oratoria a los que nos tenía a todos tan acostumbrados, mas que no por eso dejaban de ser excepcionales. Pero admiración también por la vitalidad y el apasionamiento que caracterizaban a Quintín: admiración por la pasión que sentía por todo lo que emprendía y que le permitía llegar siempre hasta las últimas consecuencias de todo lo que se proponía, y admiración por la fuerza y la valentía con las que Quintín siempre supo afrontar la vida, con todas las dichas pero también las adversidades que esta nunca deja de entrañar. Prueba indudable de ello son, por ejemplo, la energía y la entereza con las que Quintín supo encarar, al final de sus días, su enfermedad y su muerte. Pero admiración asimismo por ese extraordinario sentido del humor que nunca dejó de acompañarle y que Quintín utilizaba, en primer lugar, para reírse de sí mismo. Y admiración, finalmente, por esa enorme sensibilidad y generosidad que igualmente le eran propias y que no solo lo llevaban a detectar de inmediato, y a saber escuchar, los problemas que podían tener sus más allegados sino que asimismo lo convirtieron en lo que podríamos denominar una persona socialmente comprometida, en el más riguroso sentido de estas palabras.

Este es también, dicho en pocas palabras, el Quintín Racionero que yo he conocido, al que tanto he querido y admirado y con el que he compartido tantos y tan maravillosos momentos siempre amenizados por otra de nuestras aficiones comunes, actualmente tan denostada: la de fumar. Este es el Quintín al que aquí quiero rendir homenaje, el Quintín que me hizo el mejor regalo que puede hacérsele a alguien: el regalo de su confianza y de su amistad.

Este trabajo se encuentra bajo una licencia de Creative Commons Reconocimiento-NoComercial-SinObraDerivada 4.0 Internacional 
